\title{
Crises in Education: Online Learning as a Solution
}

\author{
Hershey H. Friedman ${ }^{1}$, Linda Weiser Friedman ${ }^{2}$ \\ ${ }^{1}$ Department of Finance and Business Management, Brooklyn College, \\ The City University of New York, New York, USA; \\ ${ }^{2}$ Zicklin School of Business, Baruch College, The City University of New York, \\ New York, USA. \\ Email: x.friedman@att.net, Linda.Friedman@baruch.cuny.edu \\ Received June $29^{\text {th }}, 2011$; revised July $18^{\text {th }}, 2011$; accepted July $22^{\text {nd }}, 2011$.
}

\begin{abstract}
There are three serious problems facing education today. These include working with draconian budgets that mean reduced spending for education, making education interesting and relevant for students, and raising standards. Several issues that the legislators are especially concerned about are the low retention rates at the college level, the high dropout rates in the high schools, and the long time it takes undergraduate students to graduate college. The authors show how online learning may be an important tool for solving these problems.
\end{abstract}

Keywords: Online Education, Low Standards, Retention Rate, Graduation Rate, School Assessment, Creativity in Education, Crises in Education, Accountability in Education

\section{Introduction}

There is concern that the United States is losing its edge as a world leader in educating its citizens (Blow, 2011; Lee, 2010). There are at least three serious problems facing educationhigher education and K-12-today. These include: working within austere budgets, making education interesting for students, and raising standards. There will be those who feel that educational standards cannot be raised without spending more money. If this is true, we are in deep trouble since most states are finding that it is difficult to raise taxes in this economic climate; pension costs and healthcare costs are soaring and a large number of people are unemployed and underemployed. It is doubtful that there will be huge amounts of money available to hire more teachers and/or reduce class size. Moreover, spending more money on the same approach to teaching may be throwing good money after the bad. An innovative solution is needed which this paper will address. First, let's examine the problems.

\section{Draconian Budgets for Education}

The first problem has to do with the challenging fiscal environment affecting almost every state thanks to the Great Recession of 2008. State budgets are quite austere and it is very doubtful that there will be money in most of them for additional buildings for universities (Lewin \& Dillon, 2010). The number of faculty at universities with tenure continues its downward trend; over the last 30 years, the number of college instructors with tenure or on a tenure track has plunged from 57\% in 1975 to below $30 \%$ today (Wilson, 2010). Increasingly, colleges are relying on adjuncts and faculty on non-tenure tracks to do much of their teaching. There is no question that the amount of money available for education will be reduced or at the very least will not be allowed to increase. Schools all over the country are being asked to be more productive. Many states are threatening to lay off teachers. According to C. Jeremiah Ryan,
President of Bergen Community College, in 1965, when the college was started, only one-third of its cost was borne by students; today students must bear $78 \%$ of the cost (Kristof, 2011). K-12 schools throughout the country have to deal with budget cuts. In New York City, for example, a last-minute deal between Mayor Bloomberg and the City Council averted layoffs for thousands of school teachers. However, the schools chancellor told principals that "individual school budgets would decline by an average of 2.4 percent" (Santos \& Hernandez, 2011).

Accountability, fiscal responsibility, and faculty productivity are the latest buzzwords in higher education as well as K-12. New metrics are being used by schools across the country to measure productivity. The Texas A \& M University system is using a spreadsheet to evaluate the gains and losses from every single faculty member. This is calculated by determining the revenues generated by a faculty member (number of students, grants, etc.) and deducting the expenses (faculty salary, costs of labs, etc.). This is also being examined by department (Simon $\&$ Banchero, 2010). The balance sheet is showing that some faculty members netted the university close to $\$ 280,000$ for the 2009 fiscal year while others cost the college about $\$ 45,000$. Some departments generate gains of more than $\$ 5$ million while others cost the college more than $\$ 1.4$ million. One metric determines amount of earnings per student taught; some professors (i.e., non-tenured lecturers) teach large classes and earn about $\$ 100$ per student while others (full professors teaching small seminar classes) earn more than $\$ 10,000$ per student (Simon \& Banchero, 2010).

Like it or not, these performance metrics are being used by more and more colleges as public officials are demanding more productivity and accountability and are examining an array of educational statistics such as graduation rates, retention rates, number of students that pass professional licensing exams (e.g., CPA), median starting salaries of graduates, average student loan debt, and other such measures. Some states are insisting that these measures be posted online so that the taxpayer should 
have a good idea as to the value of a college degree (Simon \& Banchero, 2010).

Public officials are complaining about the length of time it takes students to graduate; the typical college student takes six years and seven months to complete an undergraduate degree (Alexander, 2009). Bowen, Chingos, and McPherson (2009) found that less than $40 \%$ of students completed college in 4 years or less in the four state educational systems they examined. Alexander (2009) feels that it should not have to take four years to earn a college degree. He believes that the "idea of the fall-to-spring 'school year' hasn't changed much since before the American Revolution, when we were a nation of farmers." Back then, students helped families work their farms during the summer. It is a huge waste of resources to operate college facilities for approximately half the calendar year and allow facilities to sit idle for so much time (Alexander, 2009).

Brainard (2010) believes that colleges that offer a large number of small academic programs are at risk. Colleges all over the world are looking for ways to save money; the easiest way to do this is to close down small academic programs. According to Brainard (2010), at least $25 \%$ of all academic programs offered at a typical college are small (fewer than 7 degrees awarded in 2007-2008 AY). Programs that tend to be small are physics and Germanic languages (Brainard, 2010). Recently, SUNY Albany announced that it was shutting down programs in Classics, French, Italian, Russian, and Theater. The reason given by the president of the university was deep budget cuts (Jaschik, 2010). The choice for administrators is either to weaken all the departments in the university or to eliminate a few programs and keep the others strong.

\section{Education Can Be Boring and Irrelevant}

The second serious problem facing education is that school is simply not interesting to a significant number of students; this may partially explain the low retention rate. A large number of students quit college and fail to graduate not because of economic factors, but because they find college boring. These students need to be motivated (Carnes, 2011). Improving retention rates has become a mantra at many colleges. Derek Bok, former president of Harvard, feels that education has to move from "a teacher-oriented system featuring lectures delivered to passive audiences" to a "learner-centered process in which students become more actively involved in their own education" (Carnes, 2011).

High school principals are looking for ways to reduce the dropout rate. We have a huge high school dropout rate $-50 \%$ in various minority communities and almost $80 \%$ in Native American communities - and this demonstrates what happens when students are not finding subjects that excite them and stimulate their thirst for knowledge (Azzam, 2009). Classroom learning with a standard curriculum taught to young people of a single age group, rather than segregated by interest or abilities, may not be the way to go in the Internet Age. In fact, Robinson feels that our education system sucks out the creative capacities of young people (Robinson, 2008). Moreover, students are bored with the courses they must take. Eighty percent of teenagers say they are "marking time, trying to get through school and get out of it"; $40 \%$ of teenagers claim that success in school is something ridiculed amongst their peers and they feel pressure to do poorly (Robinson, 2005).
Brown (2000) asserts that the Web has created a "new kind of information fabric in which learning, working, and playing co-mingle." He adds that the Web is also "two-way, push and pull." The old method of lecturing passive students is a "push" approach that does not work for many students and is probably boring to them. Clearly, we have to transform education and make learning fun. It is embarrassing when television cameras show "students dozing in lecture halls" (Carnes, 2011).

Robinson (2005) believes that the current system of education is antiquated as it was designed with a production line mentality. Essentially, it was created in the $19^{\text {th }}$ Century to meet the needs of large industries as we moved away from agriculture. Industrialism back then needed workers who were literate; creativity was not that important. Before that there was no public education since the prevailing belief was that the common man could not learn very much. A classic education was for the gentleman. This changed with the Age of Enlightenment and the Industrial Revolution. Education must provide students with the tools to be creative and the ability to solve problems even when circumstances have changed so that a simple answer is not apparent.

Robinson (2005) feels that the enemy of creativity is standardization. Education today focuses on standardized exams and standardized curriculum. The corporate world needs people who understand divergent thinking, seeing multiple answers to a problem. Schools today rely heavily on standardized tests which teach students that problems have one answer. Some subjects are considered extremely important such as languages and math; others are considered unimportant such as art, music, drama, and dance. Robinson feels that the arts help develop the creativity skills that are so crucial for the leaders of the $21^{\text {st }}$ Century.

\section{Education May Have Low Standards}

Raising standards and grade inflation are issues for high school as well as college. Education Secretary Arne Duncan has predicted that it is possible that $80 \%$ of the nation's 100,000 public schools could get failing grades according to the current provisions in the federal "No Child Left Behind Law." This is why Duncan is urging Congress to rewrite the law to be more flexible (Dillon, 2011a). Duncan is threatening to grant waivers if the law is not rewritten. Congress is working on laws dealing with teacher effectiveness requirements and accountability of schools. There is a great reliance on standardized tests to determine teacher and school effectiveness. Creation of charter schools has been one supposed solution to the problem of failing schools, but clearly these schools have not been a panacea.

At K-12 schools throughout the country, evaluation systems are being used to assess teacher performance and thereby solve the problem of ineffective schools. The National Education Association has changed its position regarding teacher evaluations and is now also in agreement with the position that "evidence of student learning must be considered in the evaluations of school teachers" (Otterman, 2011a). One evaluation system known as Impact is being used to grade teachers and is becoming a model for school systems throughout the country. Evaluation of teachers is usually based on classroom observations as well as test scores of students. The big question with any evaluation system is whether it takes socioeconomic factors into account; it is much more difficult to teach in poor neighbor- 
hoods where students have many needs than in affluent, middle class neighborhoods (Dillon, 2011b). Shapiro (2004: p. 167) asserts:

"Educational quality results primarily from where children live and the resources their parents provide... As we have seen, quality schools and substandard schools are not distributed randomly; schools commonly reflect a community's wealth and class and race composition."

Thus, it is not only the children attending the middle class schools that have an advantage; it may also be the faculty teaching there.

Many high schools are graduating students that do not have the required skills to do well in college. New York City, for example, is tracking City University of New York (CUNY) remediation rates, the percentage of high school students who fail at least one CUNY entrance exam and therefore need remediation. Also, monitored are high school graduation rates. The graduation rate from NYC high schools rose to $61 \%$ in 2010 from $52.8 \%$ in 2007 . However, the remediation rate was $49 \%$ in 2010; it was 45\% in 2007 (Phillips and Gebeloff, 2011). About two-thirds of high schools that were rated A in NYC by the Education Department's School Assessment System had remediation of $50 \%$ or more (Phillips and Gebeloff, 2011). One can safely assume that this problem of high school graduates needing remediation is not limited to New York City.

Ravitch (2011) warns of the dangers of relying too heavily on test scores. Often, the improvements are fleeting and scores return to "normal" after a year or two. She cites the example of PS 33 in the Bronx where there was an amazing improvement-from $34 \%$ in 2004 to $83 \%$ in 2005 -in the percentage of students who met minimum state reading standards. Mayor Bloomberg of NY held a news conference to tout the success of his changes in education. Unfortunately, by 2010 , the pass rate was at $37 \%$. Ravitch (2011) emphasizes that there are no miraculous solutions to make schools better. Coming from a stable family that encourages learning is probably more important when it comes to education than quick fixes involving firing principals and teachers and / or shutting down schools.

Arum and Roksa (2011) claim that a significant number of college students only barely improve their skills in the vital areas of critical thinking, writing, and problem solving/critical reasoning. Indeed, after four years, $36 \%$ had made no significant gains in those three areas. The average amount of time that college students spend studying is now less than half of what it was in the 1960s.

Many of us still remember when the United States was a world leader in education. Today, we are doing poorly on many measures of performance when it comes to education. We are, however, a world leader when it comes to "Prison Population per 100,000 citizens"-743 is probably the highest in the world. When it comes to education, our scores on the math scale (487) and the science scale (502) are pathetic (Blow, 2011). Blow (2011) makes the point that many others have made:

Financing for education and social services isn't simply about handouts to the hardscrabble, it is about building an infrastructure that can produce healthy, engaged and well-educated citizens who can compete in an increasingly cutthroat global economy

The scores for the 2009 PISA (Program for International Student Assessment) test indicated that United States 15-year olds scored $17^{\text {th }}$ in reading, $23^{\text {rd }}$ in science, and $31^{\text {st }}$ in math out of 65 countries tested. It is clear, according to Arne Duncan, that "we're being out-educated." The countries that did very well on the PISA test were China, South Korea, and Finland (Lee, 2010).

\section{Goals of Education}

Before addressing the solution to the twin problems of education being boring and ineffective, it is important to answer the question of "What are the goals of education?" This is not a trivial question. The world has changed thanks to the Internet and skills that were valuable in the past may not be so important today. As an example, take spelling. Is this a valuable skill in the age of spelling checkers? Few high schools teach students how to calculate logarithms and square roots using the old methods; this is all done with calculators. Is there any value in this day and age to know how to calculate a standard deviation with a pencil and paper?

We have progressed far beyond the days when a school taught the "three R's" of reading, writing, and arithmetic. Many schools have lists describing the goals of general education that include critical thinking, mathematical reasoning, ability to communicate, understanding the importance of cultural diversity, ability to make ethical judgments, appreciation of the fine arts, encouragement of lifelong learning, and more. Some feel that there are essentially three skills students must have in order to succeed in the knowledge economy: “... critical thinking and problem solving; the ability to communicate effectively; and the ability to collaborate" (Friedman, 2010). Most would agree that the true job of an educator is to provide students with an unquenchable thirst for knowledge and the ability to acquire it. Albert Einstein once said: "I never teach my pupils. I only attempt to provide the conditions in which they can learn" (Moncur, 2004).

It is becoming apparent that the ability to work productively with others is an important goal of education. Collaboration and teamwork are vital in almost every enterprise. Hardly any occupation allows individuals to work alone without input from others. Learning how to communicate and work with others should also be a goal of education (Robinson, 2008). It is very difficult to be creative in this day and age if one works alone. Indeed, the ability to communicate has little value if one does not possess the ability to be part of a team. Pink (2006: p. 3) believes that "the defining skills of the previous era'left-brain' capabilities that powered the Information Age-are necessary but no longer sufficient." The skills that are valuable today, in the Conceptual Age, include such factors as creativity, empathy, happiness, and meaning.

Surprisingly, skills such as storytelling, which requires the ability to communicate in a creative way, are important in the business world. Xerox, for example, discovered that repair personnel used stories rather than information in manuals as a way of finding out what was wrong with a machine. These stories were collected and are now part of a database (Eureka) that is worth millions to Xerox (Pink, 2006: p. 108). Medical schools are teaching future physicians to listen empathetically to patients' ailments. These ailments are told in narrative form and the ability to interpret and respond to the stories is crucial if a doctor wants to heal the patient (Pink, 2006: p. 112).

Even the disciplines of today are changing rapidly because of 
convergence. There are many more specialties today than in the past and there is much more "boundary crossing and interdisciplinary activity" (Klein, 1996: p. 42). Klein (1996: p. 191) asserts: "Almost all significant growth in research in recent decades, the committee [National Research Council] concluded, has occurred at the 'interdisciplinary borderlands' between established fields." It is unrealistic to believe that an educator from one discipline will be able to provide the necessary knowledge to solve problems that will arise two decades, or even 10 years later. This means that successful people will need the ability to work and communicate with individuals from other disciplines. This is another reason that an appreciation of diversity is so important. It is not only about ethnic diversity but also diversity of ideas.

According to Robinson (2005), companies today believe the most important challenge is "finding people who could make good decisions in times of uncertainty, who can adapt to new opportunities and respond creatively to change." He observes that in 1997, only 74 companies of the original Standard \& Poor list of top 500 corporations (published in 1957) were still around (Robinson, 2005).

Brown (2000) is of the opinion that the goal of education is to teach students information navigation, i.e., how to find useful information on the Internet. Students know how to use the Internet for social reasons, but many do not have the tools to use it to find reliable, valid information. The day where students go to the brick-and-mortar library and find books and magazines to do research is almost obsolete. Today, a good researcher knows how to use the Internet.

Thus, the goals of education have to go beyond the three R's in the Internet/Conceptual Age. The following skills are necessary:

Critical Thinking. Creativity. The ability to think critically, creatively, and outside one's discipline. This entails the facility to respond quickly and decisively and make decisions when the business environment changes.

Lifelong learning. A love for learning that will ensure that one is always acquiring knowledge.

Communication and collaboration. The ability to collaborate and work with others using all kinds of computer technology including Wikis, blogs, etc. This includes the capability to work with people with all kinds of backgrounds from all over the world.

Information literacy. The ability to navigate the Internet and retrieve useful information

\section{Online Learning as a Solution}

There is a great deal of evidence that supports the view that online learning is effective with college students. Courses that blend online with traditional classroom learning appear to be the most effective way to teach courses for college students. Means et al. (2009) did a meta-analysis of more than 1000 studies published from 1996 to 2008 comparing online with traditional classroom teaching. What they found was that online learning does offer many advantages over traditional classroom learning. In fact, students who take courses that are either completely or partially online will perform better than students taking traditional, face-to-face courses. Interestingly, hybrid courses that combine classroom learning with online learning seem to be the best of all delivery methods. Means et al. (2009) conclude:

"Despite what appears to be strong support for online learning applications, the studies in this meta-analysis do not demonstrate that online learning is superior as a medium. In many of the studies showing an advantage for online learning, the online and classroom conditions differed in terms of time spent, curriculum and pedagogy. It was the combination of elements in the treatment conditions (which was likely to have included additional learning time and materials as well as additional opportunities for collaboration) that produced the observed learning advantages. At the same time, one should note that online learning is much more conducive to the expansion of learning time than is face-to-face instruction."

Diana G. Oblinger, president of Educause, made the following statement in response to the above study: "Online education provides additional opportunities. It gives people greater opportunity for flexibility, for experiential learning, for illustrating things in multiple ways such as visualization." She emphasized that the study makes it quite obvious that colleges have to make sure to use online education and not insist on only offering courses using traditional, face-to-face instruction (Jaschik, 2009).

The Open Learning Initiative at Carnegie Mellon University has been using hybrid courses that combine online and traditional classroom courses to accelerate learning. In one study involving different approaches to teach statistics, a comparison was made of a traditional class with a hybrid class. The traditional class met for 15 weeks, 4 times a week. The hybrid class met twice a week for $71 / 2$ weeks. Students in the hybrid class had test scores and retention scores that were equal to or better than those for the students in the traditional classroom (Lohr, 2010). It appears that a hybrid approach can enhance productivity even with a course as difficult as statistics.

Bernard et al. (2009) performed a meta-analysis on the distance education literature and examined three types of interaction treatments: student-student (SS), student-teacher (ST), and student-content (SC). Student-student interaction may be built into distance education courses through the use of group projects. Student-teacher interactions are easy in hybrid courses where there are some face-to-face meetings and a bit more difficult in fully online courses. Even with fully online courses, student-teacher interactions can occur via the use of email, phone calls, discussion boards, chats, and videoconferencing. Student-content interactions can be effected by having students read online material, collect information, or watch a video. Brown (2000) claims that classes that use a taped lecture format in which a group of students that can stop the tape every few minutes so that the group can discuss it and clarify ambiguities is superior to the traditional classroom lecture. This approach allows student-student interaction which can enhance learning.

Bernard et al. (2009) conclude that all three types of interactions are important and should be an important part of fully online courses since they enhance student learning as well as satisfaction. Web 2.0 technologies are making it less costly and much easier for students to collaborate and to engage in student-student interaction. The research in the field is supporting the idea that three kinds of interaction are very important in learning (Wanstreet, 2006; Swan, 2002). Battalio (2007), however, concludes that not all students have the same learning 
styles. Some students may prefer learning in a traditional, faceto-face environment; others may thrive in fully online courses. The belief that the best way for students to learn is via traditional, face-to-face classes is rapidly becoming obsolete. The best one can claim is that the traditional class offers advantages for some students.

There are many advantages to offering online classes both at the high school level as well as in colleges. The following are just a few of the advantages.

\section{Online Education as a Way to Save Money}

It is evident that academe will have to learn to be more productive. Education will have to learn from what retailers have done. Many retailers have moved from a brick-and-mortar approach to a click-and-mortar approach. This means fewer buildings but an expanded presence on the Internet; consumers can make purchases both at physical stores and online. Thus, for example, Wal-Mart sells products at many stores but also does a brisk business online. The publishing industry has also made changes to its business model. E-books may not totally replace paper books but companies that want to survive must offer both. College textbook publishers currently offer both types of books as well as a great deal of material using the web. Textbooks often come with a homework manager that enables students to do homework online and get immediate feedback. Banks have buildings but also provide service at thousands of ATMs throughout the world.

Colleges and universities will also have to become flexible. By offering more online and hybrid courses, less physical space will be required. Traditionally, a college would offer a 3-credit class, say, on Monday/Wednesday from 9:15 AM to 10:30 AM in a particular room. With hybrid classes (say, $50 \%$ online), the same room could be used for two hybrid sections: one meeting on Monday from 9:15 AM to 10:30 AM and the other meeting in the same room on Wednesday from 9:15 AM to 10:30 AM. Using a click and mortar approach to education would reduce the needs for physical space. With fully online classes, the need for physical plant is reduced even further.

There is a growing need for educating the nation's labor force. It is obvious that most new jobs require considerably more than just a high school diploma. Today's jobs require at the very least a community college degree (Lohr, 2010). Unfortunately, state budgets are being very drastically cut and there will be little or no money to expand postsecondary education. This is a key reason that several foundations including the Bill and Melinda Gates Foundation and the William and Flora Hewitt Foundation are providing funds for postsecondary online courses. The Next Generation Learning Challenges is targeted to college students and is seeking innovative technological tools that can be shared by colleges and used to assist teachers. The goal is to develop online courses and tools to expand education without increasing state budgets that are already stretched too thin (Lohr, 2010). MIT is already making online lectures and coursework available on the Internet to the public via its OpenCourseWare website (http://ocw.mit.edu/ courses/). An organization that was established to help spread knowledge via the Internet by making courses and lectures available to all is Academic Earth. Academic Earth states on its website that it "is an organization founded with the goal of giving everyone on earth access to a world-class education" (http://academicearth.org/).

Money is tight and colleges need students. Unfortunately, students today have to work to pay for their steadily-rising tuition. College students are highly likely to work while pursuing a degree. In fact, about $78 \%$ of college students had at least part-time employment during the 2003-2004 academic year. On average, students worked approximately 30 hours per week (American Council on Education, 2006). This means that students will often require very flexible schedules. Many students are receiving financial aid which means that they will have to be full time. It can be quite daunting to be a full-time student and work for 30 hours per week when all courses are traditional. By offering a blend of traditional, hybrid, and fully online courses, it is less difficult to find courses to take. On the other hand, one serious disadvantage of colleges that are completely online is that students miss out on the college-life experience. Colleges that use the click-and-mortar approach and offer online as well as traditional courses allow for college life and indeed may open it up to a wider audience who otherwise could not afford to go to college.

\section{Enhancing Creativity and Making Classes More Interesting}

There was a time when laughter was seen as a problem in the workplace. People on the assembly line at Ford Motor Company during the 1930s and 1940s were fired for laughing or smiling while working. Ford's philosophy was: "When we are at work, we ought to be at work. When we are at play, we ought to be at play. There is no use in trying to mix the two." Today, many firms want employees to be happy at work since they feel it increases productivity and profits. The mission statement of Southwest Airlines says it all: "People rarely succeed at anything unless they are having fun doing it." (Pink, 2006: pp. 186-187; Collinson, 2002). The same might be done for education: teach students to be creative and make learning fun. This can be accomplished by using online tools and not relying solely on classroom lectures.

Many educators sneer at video games and think that they are a waste of time. Some video games may not be a waste of time in the Conceptual Age. Studies are finding that playing video games may sharpen the skills of physicians involved in laparoscopic surgery and help in decision making (Pink, 2006: 193). Gee (2003) feels that "when kids play video games they can experience a much more powerful form of learning than when they're in the classroom. Learning isn't about memorizing isolated facts. It's about connecting them and manipulating them." The right kind of video game may help enhance the creativity of students while making education interesting. Students today are more likely to find a game more fun than a lecture. Courses that are offered fully or partially online can enhance creativity since they can use numerous teaching tools that include animations, videos, wikis, blogs, web links, webinars, and virtual labs.

Brown (2000) asserts that young people today are always "multiprocessing" and conducting several tasks simultaneously. Many can be working on the computer, talking on their cell phones, and listening to music, all at the same time! One can imagine how bored students might be with the traditional approach where the instructor lectures while students take notes. Asking students to listen to a YouTube lecture given by a 
recognized scholar may be more effective than lecturing. One suspects that watching a television show on the History Channel might be more effective than having students listen to a lecture about the same subject. At the very least, an online course can use different approaches to teaching material.

As noted above, standardization is the enemy of creativity. It is true that all students need certain basic skills. However, does this mean that all students should take the same courses? Most high schools do not have the resources to offer more than a few electives. This, in effect, means that almost everyone takes the same courses. This reminds one of a prison cafeteria: all prisoners have to eat the same food. Variety is a luxury not available to people in prison Schools, however, are not prisons. Young people need variety; not everyone is interested in the same subjects.

There are high schools in New York that are allowing students to earn credits in innovative ways. To graduate from a New York City public high school, a minimum of 44 credits must be earned- 8 credits in English; 8 credits in Social Studies; 6 in Science; 6 in Math; 2 in Art; 2 in Foreign Language; 4 in gym; 1 in Health; and 7 elective credits (Otterman, 2011b). One high school allows students to take a sailing course to earn science or gym credit. The course is offered for free by a nonprofit organization in NYC. The curriculum was developed with the help of a teacher who is certified. In order to receive math credit, students solve distance problems involving sailing a boat and taking into account speed and wind conditions. Students learn practical applications of trigonometry in sailing boats (Otterman, 2011b). Some students earn physical education credits by volunteering at fitness centers in the various Y.M.C.A.s in the city. Some high schools allow students to earn credits via internships; some students have internships at a film-making studio that teach them how to write and produce documentaries.

Offering online courses to young people may be a simple way for schools ranging from kindergarten through graduate school to broaden the offerings. Students in high school can be offered a "cafeteria" education which allows them to choose the courses they wish to take instead of everyone taking exactly the same courses. Certainly, every student has to be taught basic reading, writing, and arithmetic skills. However, there is no reason to have students take almost the same courses from K-12. Also, using online courses allows students to learn at their own pace. Logically, there is no reason that every student taking, say, a high school course in biology should have one academic year to learn the course. People learn at different rates. Schools that wish to encourage creativity should give students flexibility as to which courses to take (with the understanding that some courses are required of all) and how much time to spend on the course. Students should be able to complete the course in two months, rather than 10 months, if they have the ability and interest. The idea that everyone has to be in high school for four years is another idea that must be rethought. Clearly, something must be wrong if a significant number of students are truant on a regular basis and drop out as soon as they are legally permitted to do so.

Websites such as Academic Earth and YouTube EDU which collect free lectures from top institutions such as Harvard, MIT, Princeton, and Yale and make them accessible in one place have made it very easy to offer courses to students with an in- terest in exotic areas. Universities such as Brigham Young University currently offer online courses to junior high school students (http://ce.byu.edu/is/site/). Eventually, we will see free websites that offer classes for students of all ages. One entrepreneur, Shai Reshef, has created a free online University. Reshef is the chairman of Cramster, an online study community for high school and college students where they can get help with their homework. According to the mission statement of the university (http://www.uopeople.org/groups/mission):

"University of the People (UoPeople) is a non-profit organization devoted to providing universal access to quality, online post-secondary education to qualified students. The vision of University of the People is grounded in the belief that universal access to education is a key ingredient in the promotion of world peace and global economic development."

There are some exciting courses given all over the world. Online is one way to bring these courses to any school or college. For example, Michael J. Sandel, the Harvard University political philosopher, offers a class in "Justice" that is world renown and is among the most popular courses ever offered there. The course addresses questions such as: "How much is a human life worth?"; "Is it ever wrong to tell the truth?"; and "Would you steal a drug to save your child's life?" Approximately 15,000 Harvard University students have taken the course. The classes are now available online for free at www.justiceharvard.org (Friedman, 2011). Harvard's most popular course, "Positive Psychology," known as the "happiness course"-it teaches students the secret of being happyis also available online. This is a course offered by Professor Tal Ben-Shahar and attracts close to 900 students per semester.

Closely tied to the idea of creativity is reconsidering the college curriculum, especially the major. The traditional belief is that the idea of an academic major dates back to 1877 and first appeared in a Johns Hopkins University catalog (Glenn \& Fischer, 2009). Today, virtually every college requires a specialized major. The amount of knowledge continues to increase exponentially which means that the number of departments, minors, and majors should be increasing. Indeed, there are a large number of majors (and jobs) today that did not exist 20 years ago. Harvard College reorganized into six "departments" back in 1815 . It should be noted that those were not actually departments as we define them today; the modern departmental structure actually dates back to somewhere around the 1890 s (Klein, 1996: p. 53).

There is now strong evidence that the value of an undergraduate college degree depends on the major (Supiano, 2011); median income for counseling-psychology majors was the lowest $(\$ 29,000)$ and highest for petroleum-engineering majors $(\$ 120,000)$. It should also be noted that the returns from a college degree are about $15 \%$ per annum; college graduates, on average, earn $83 \%$ more than those with only a high school diploma (Leonhardt, 2011). Major may affect one's earnings but there is a considerable amount of evidence that a college graduate performing a job that does not require a degree-e.g., dishwasher, childcare worker, dental hygienist, hairdresser, cashier, plumber, firefighter, secretary, etc.-will still earn considerably more than a high school graduate doing the same job (Leonhardt, 2011).

The top 10 majors during the 2006-2007 academic year were about the same (with a somewhat different order) as those of 
the 1980-1981 academic year (Glenn \& Fischer, 2009). This is not necessarily a good thing given how much has changed in the last 25 years. In many colleges, it is very costly to introduce new majors in response to the demands of the market, because of some new social/cultural concern, or because of a scientific innovation. There is no way to know whether an area that is popular today will be in demand 10 years later. Sometimes, one area can grow into dozens of areas. For example, in the 1960s, many colleges opened up an Africana Studies department in response to the growing social concern with the way African-Americans were being treated. Today, these schools may have departments of Asian Studies, Jewish Studies, Italian Studies, Puerto Rican/Latino Studies, Children Studies, Middle Eastern Studies, Gay Studies, and Women's Studies.

Allowing students to create their own majors is another way to enhance creativity. The cost of doing so is not prohibitive if online courses from other universities can be utilized. For instance, a student might be able to major in alternative energy and use the Internet to find courses that might not be available in his/her own college. The problem of small programs can be solved if these programs are online. Providing online courses to supplement regular courses can also help students seeking minors. There is some controversy as to whether a minor is a good idea or not (Slatalla, 2008). There are those who feel it provides an edge in the job market by signaling to potential employers that one has some specialized knowledge in another discipline. For example, a minor in a foreign language sends a very strong message regarding some very concrete knowledge that an applicant possesses. Online courses can also make it easier to offer a wide variety of minors to interested students.

Solutions to problems will require creative people who think outside the discipline and are not constrained by the models and methods of a single discipline (Friedman, Friedman, \& Pollack, 2008). Online courses offer an inexpensive way for students to add minors and/or second majors and thereby provide students with the flexibility necessary to see how other disciplines deal with problems.

\section{Improving Student Proficiency in K-12}

Unfortunately, there is very little research on the value of online education when it comes to K-12 (Means et al., 2009). There is some evidence, however, that schooling can help increase the IQ of students. IQs actually drop during summer vacation when children are not in school (Nisbett, 2009). Nisbett (2009) believes that government should invest in intensive early childhood programs such as the Knowledge is Power Program (KIPP). More education results in higher IQ scores for children and higher IQ scores are correlated with success. It is quite obvious that it is probably too costly for most countries to keep schools open for most of the summer. However, it may not be that difficult to try offering a limited number of online courses for high school students. The cost would be reasonable and this way students can practice reading, writing, and some arithmetic during the summer. This way, they would not forget everything they learned during summer vacation. Online education can also be used on children before starting school at the age of 6. Children can learn a great deal between the ages of 3 and 6 and a Head Start Program that is fully online should be tested.

Online courses can be used to make the senior year of high school more interesting. It may also allow some students to complete high school in three years. Many students do not accomplish much in the senior year of high school and it might be an ideal time to offer online college courses for credit.

\section{Conclusion}

Institutions across the country have increased their offerings of online and hybrid programs and classes. The flexibility and convenience of these programs provide more opportunity for individuals to achieve their goal of more personal and professional development, while increasing brand and revenue potential for the institution. There were more than 4.6 million students enrolled in at least one online course in the U.S. during fall 2008, with about 83 percent studying at the undergraduate level, 14 percent at the graduate level and the rest in some "other" for-credit course (Allen \& Seaman, 2010). While the number of programs and courses online continue to grow, the acceptance of this learning modality by faculty has been relatively constant since first measured in 2002 (Allen \& Seaman, 2010).

Given the crises in education, the authors feel that schools from kindergarten to doctoral programs should be experimenting with online classes. Reliance on additional funding from government for education is probably not realistic and any solution to improve the educational system in the United States will have to be cost-effective. Online classes are not a panacea but, if used wisely, can help improve student learning and allow schools to offer a greater selection of interesting courses. It may also help reduce the dropout rates at the high school and college level. There are some who believe that "the general skills that colleges teach, like discipline and persistence, may be more important than academics anyway" (Leonhardt, 2011). If this is the case, then online may be even more valuable as a tool than traditional classroom teaching in instructing students in discipline and persistence. Offering online courses could help improve the time it takes to complete a degree and simultaneously reduce the need for brick-and-mortar facilities.

\section{References}

Alexander, L. (2009). Why colleges should take only 3 years. Newsweek, 26-29.

Allen, I. E. and Seaman, J. (2010). Learning on demand: Online education in 2009. Sloan Consortium. Retrieved from

http://sloanconsortium.org/publications/survey/pdf/learningondeman d.pdf

American Council on Education (2006). Working their way through college: Student employment and its impact on college education. Acenet.edu. Retrieved from

http://www.acenet.edu/AM/Template.cfm?template $=/ \mathrm{CM} /$ ContentDi splay.cfm\&ContentFileID $=1618$

Arum, R., \& Roksa, J. (2011). Academically adrift: Limited learning on college campuses. Chicago: University of Chicago Press.

Azzam, A. M. (2009). Why creativity now? A conversation with Sir Ken Robinson. Teaching for the $21^{\text {st }}$ Century, 67, 22-26.

Battalio, J. (2007). Interaction online: A reevaluation. Quarterly Review of Distance Education 8 (4), 339-352.

Bernard, R. M., Abrami, P. C., Borokhovski, E., Wade, C. A., Tamim, R. M., Surkes, M. A., \& Clement Bethel, E. (2009). A meta-analysis of three types of interaction treatments in distance education. Review of Educational Research, 79, 1243-1289. 
doi: $10.3102 / 0034654309333844$

Blow, C. M. (2011). Empire at the end of decadence. New York Times, A23.

Bowen, W. G., Chingos, M. M., \& McPherson, M. S. (2009). Helping students finish the 4-Year run. Chronicle of Higher Education, A28A29.

Brainard, J. (2010, April 2). Having a multitude of small academic programs is common - but risky. Chronicle of Higher Education, A12.

Brown, J. S. (2000). Growing up digital: How the web changes work, education, and the ways people learn. Change, 11-20. doi:10.1080/00091380009601719

Carnes, M. C. (2011). Setting students' minds on fire. Chronicle of Higher Education, 57, A72.

Collinson, D. L. (2002). Managing humour. Journal of Management Studies, 39, 269-288. doi:10.1111/1467-6486.00292

Dillon, S. (24 June 2011a). Republican challenges administration on plans to override education law. New York Times, A12.

Dillon, S. (28 June 2011b). Teacher grades: Pass or be fired. New York Times, A1, A16.

Friedman, L. W., Friedman, H. H., \& Pollack, S. (2008). The role of modeling in scientific disciplines: A taxonomy. Review of Business, 29, 61-67.

Friedman, T. L. (21 November 2010). Teaching for America. Week in Review, New York Times, 8.

Friedman, T. L. (15 June 2011). Justice goes global. OP-ED, New York Times, A27.

Gee, J. P. (2003). High score education: Games, not school are teaching kids to think. Wired. URL (last checked May 2003) http://www.wired.com/wired/archive/11.05/view.html

Glenn, D. and Fischer, K. (2009). The canon of college majors persists amid calls for change. Chronicle of Higher Education. URL (last checked 31 August 2009)

$\mathrm{http}: / /$ chronicle.com/article/Amid-Calls-for-Change-College/48206/

Jaschik, S. (2009). The evidence on online education. Inside Higher Education. URL (last checked 26 June 2009)

http://www.insidehighered.com/news/2009/06/29/online

Jaschik, S. (2010). Disappearing languages at Albany. Inside Higher Education. URL (last checked 4 October )

http://www.insidehighered.com/news/2010/10/04/albany

Klein, J. T. (1996). Crossing boundaries: Knowledge, disciplinarities, and interdisciplinarities. Charlottesville, VA: University Press of Virginia.

Kristof, N. D. (5 June 2011). Our fantasy nation. Week in Review. New York Times, 9.

Lee, K. (2010). Math, science, reading scores show U.S. schools slipping behind. PBS Newshour Extra. URL (last checked 10 December 2010)

http://www.pbs.org/newshour/extra/features/us/july-dec10/education 12-10.html

Leonhardt, D. (26 June 2011). Even for cashiers, college pays off. New York Times, Sunday Review, 3.

Lewin, T. and Dillon, S. (2010). School districts warn of deeper teacher cuts. New York Times, URL (last checked 20 April 2010) http://www.nytimes.com/2010/04/21/education/21 teachers.html

Lohr, S. (11 October 2010). In higher education, a focus on technology.
New York Times, B3.

Means, B., Toyama, Y., Murphy, R., Bakia, M., \& Jones, K. (2009). Evaluation of evidence-based practices in online learning: A metaanalysis and review of online learning studies. U.S. Department of Education Office of Planning, Evaluation, and Policy Development, Policy and Program Studies Service. URL (last checked 2009) http://www2.ed.gov/rschstat/eval/tech/evidence-based-practices/final report.pdf

Moncur, M. (2004). The quotations page. URL (last checked 2004) $\mathrm{http}: / /$ www.quotationspage.com/quotes/Albert_Einstein/

Nisbett, R. E. (2009). Intelligence and how to get it. New York: W. W. Norton \& Company.

Otterman, S. (5 July 2011a). Union shifts position on teacher evaluations. New York Times, A15.

Otterman, S. (27 June 2011b). Taking a spin on the Hudson, and earning course credit, too. New York Times, A18.

Phillips, A. M. and Gebeloff, R. (22 June 2011). In data, 'A' schools leave many not ready for CUNY. New York Times, A18.

Pink, D. H. (2006). A whole new mind. New York: Riverhead Books.

Ravitch, D. (2011). Waiting for a school miracle. OP-ED. New York Times, A27.

Robinson, K. (2005). How creativity, education and the arts shape a modern economy. Education Commission of the States: Arts and Mind Series. URL (last checked April 2005) http://www.ecs.org/clearinghouse/60/51/6051.pdf

Robinson, K. (2008). RSA animate: Changing education paradigms. URL (last checked 2008)

http://www.youtube.com/watch?v=zDZFcDGpL4U\&feature=email

Complete lecture at: http://wn.com/Sir_Ken_Robinson_CChanging_Paradigms

Santos, F., \& Hernandez, J. C. (28 June 2011). Even without teacher layoffs, city schools will still feel pain. New York Times, A18.

Seaman, J. (2009). Online learning as a strategic asset: The paradox of faculty voices: Views and experiences with online learning. Washington D.C.: Association of Public and Land-grant Universities.

Shapiro, T. M. (2004). The hidden cost of being African-American: How wealth perpetuates inequality. New York: Oxford University Press.

Simon, S., \& Banchero, S. (2010). Putting a price on professors. Wall Street Journal. URL (last checked 22 October 2010) http://online.wsj.com/article/SB100014240527487037358045755363 22093520994.html

Slatalla, M. (20 April 2008). What's your minor? New York Times. Education Life. 10-11.

Supiano, B. (June 3 2011). What's a degree worth? Report has answers by major. Chronicle of Higher Education, A20.

Swan, K. (2002). Building learning communities in online courses: The importance of interaction. Education, Communication \& Information, 2, 23-49. doi:10.1080/1463631022000005016

Wanstreet, C. E. (2006). Interactions in online learning environments: A review of the literature. Quarterly Review of Distance Education, 7, 399-411.

Wilson, R. (2010). Tenure, RIP: What the vanishing status means for the future of education. Chronicle of Higher Education. URL (last checked 2010) http://chronicle.com/article/Tenure-RIP/66114 